\title{
Analisa Parameter Fisika dan Kimia Perairan Tihik Tihik Kota Bontang untuk Budidaya Rumput Laut Kapphaphycus alvarezii
}

\author{
Andi Nikhlani ${ }^{1^{*}}$ dan Indrati Kusumaningrum ${ }^{2}$ \\ Jurusan Budidaya Perairan, Fakultas Perikanan dan IImu Kelautan \\ Universitas Mulawarman, Samarinda \\ 1 Email: andini.makmur@yahoo.com
}

*Penulis korespondensi: andini.makmur@yahoo.com

Submit: 24-8-2021

Revisi: 11-12-2021

Diterima: 22-12-2021

\begin{abstract}
Seaweed is one of aquaculture organism species it has a potential to be developed in Bontang City. Kapphapycus alvarezii is the largest carrageenan-producing red algae species from Indonesia's export volume. The research aimed was to determine the feasibility of water quality in Tihik Tihik Waters Bontang City based on the waters physical and chemical aspects. The research method was an observation method. This research was conducted on April 21 up to May 17, 2021. The sampling locations were divided into 5 points. Sampling in each station was conducted 3 times. The research results showed that the water quality ranges in these waters were (1) the water temperature ranged 29.0-30.10C; (2) degree of acidity ranged 7.5-8.6; (3) dissolved oxygen ranged 3.65-4.0 ppm; (4) Waters salinity ranged 30.0-32.5 psu; (5) brightness ranged 120.5-132.3 cm; (6) current speed ranged 0.19 to $0.25 \mathrm{~m} / \mathrm{s}$; (7) depth ranged $9.10-13 \mathrm{~m}$; (8) nitrate ranged 0.04-0.05 mg/L; (9) Phosphate ranged 0.06-0.13 mg/L; (10) total suspended solids ranged 5-7 mg/L Based on the water quality parameters is, it's can be known that the Tihik Tihik waters of Bontang City feasible to be used as a location for Kapphaphycus alvarezii seaweed cultivation.
\end{abstract}

Keywords: Aquaculture, Kapphaphycus alvarezii, Seaweed, Tihik Tihik, Water Quality

\begin{abstract}
ABSTRAK
Rumput laut merupakan salah satu jenis organisme budidaya yang berpotensi untuk dikembangkan di Kota Bontang. Kapphapycus alvarezii merupakan spesies alga merah penghasil karagenan terbesar dari volume ekspor Indonesia. Tujuan penelitian ini adalah untuk mengetahui kelayakan kualitas air di Perairan Tihik Tihik Kota Bontang berdasarkan aspek fisika dan kimia perairan. Metode penelitian berupa metode observasi. Penelitian ini dilaksanakan pada tanggal 21 April sampai dengan 17 Mei 2021. Lokasi pengambilan sampel terbagi atas 5 titik Pengambilan sampel di tiap stasiun dilakukan sebanyak 3 kali. Hasil penelitian memperlihatkan kisaran kualitas air pada perairan tersebut adalah (1) suhu perairan berkisar $29,0-30,1^{\circ} \mathrm{C}$; (2) derajat keasaman berkisar 7,5-8,6; (3) oksigen terlarut berkisar 3,65-4,0 ppm; (4) salinitas perairan berkisar 30,0-32,5 psu; (5) kecerahan berkisar 120,5-132,3 cm; (6) kecepatan arus berkisar 0,19-0,25 m/s; (7) kedalaman berkisar 9,10-13 m; (8) nitrat berkisar 0,04-0,05 mg/L; (9) Phosfat berkisar 0,06-0,13 mg/L; (10) total suspended solid berkisar 5-7 mg/L. Berdasarkan hal tersebut dapat diketahui bahwa perairan Tihik Tihik Kota Bontang layak digunakan sebagai lokasi budidaya rumput laut Kapphaphycus alvarezii.

Kata kunci: Akuakultur, Kapphaphycus alvarezii, Kualitas Air, Rumput Laut, Tihik Tihik
\end{abstract}




\section{Pendahuluan}

Bontang merupakan salah satu daerah di Provinsi Kalimantan Timur yang memiliki potensi untuk pengembangan budidaya rumput laut. Potensi pengembangan budidaya rumput laut di Kota Bontang tergolong menjanjikan. Menyadari besarnya potensi tersebut, Pemerintah Kota Bontang melalui Departemen Kelautan dan Perikanan (2005), terus berupaya menggali potensi rumput laut yang dimiliki. Pemerintah Bontang telah menetapkan target produksi rumput laut kering di Bontang sebesar 400 ton per bulan. Hal ini dilakukan sebagai upaya mendukung dan menyiapkan bahan baku yang dibutuhkan pabrik pengolahan rumput laut. Rumput laut yang banyak dibudidayakan didaerah Bontang adalah rumput laut jenis Kapphapycus alvarezii.

Kapphapycus alvarezii merupakan spesies alga merah yang merupakan penghasil karagenan dan merupakan bagian terbesar dari volume ekspor Indonesia (Zainuddin \& Rusdani, 2018). Kajian intensif oleh Kumayanjati \& Dwimayasanti (2018) menunjukkan bahwa karagenan digunakan secara luas untuk berbagai kepentingan industri pangan, kosmetika dan obat, bahkan untuk kesehatan seperti potensinya sebagai anti virus berbagai penyakit seperti herpes, hepatitis $A$, genital human papillomaviruses (HPV), dan blocking virus HIV pada wanita.

Kualitas rumput laut berkaitan erat dengan faktor-faktor pada saat budidaya seperti metode dan pemilihan lokasi budidaya, iklim dan geografis Indonesia seperti sinar matahari, arus, tekanan dan kualitas air serta kadar garam. Faktor-faktor tersebut harus sesuai dengan kebutuhan biologis dan pertumbuhan rumput laut. Rumput laut mampu menyerap sinar matahari dan nutrisi air laut secara optimal dan menghasilkan rumput laut yang kaya akan polisakarida (agar-agar danlemak), phaeophyceae (alginat), chlorophyceae (kanji dan lemak). Salah satu faktor yang menyebabkan rendahnya komposisi nutrisi, mutu karagenan dan agar adalah pemilihan lokasi budidaya yang tidak tepat (Risnawati et al.,2018).

Parameter lingkungan yang menjadi penentu lokasi yang tepat untuk budidaya rumput laut adalah kondisi lingkungan fisik yang meliputi kedalaman, kecerahan, kecepatan arus, muatan tersuspensi (MPT) atau Total Suspended Solid (TSS), dan lingkungan kimia yang meliputi salinitas, derajat keasaman, oksigen terlarut, nitrat dan phosfat (Nur et al., 2016). Kondisi lingkungan fisik dan kimia ini penting untuk diketahui karena sifat fisik dan kimia perairan sangat berpengaruh terhadap pertumbuhan serta kadar keragenan rumput laut yang dihasilkan. Berdasarkan studi referensi dan hasil penelitian yang ada, maka peneliti tertarik untuk melakukan penelitian tentang sifat fisik dan kimia perairan kawasan budidaya Kapphaphycus alvarezii di perairan Tihik Tihik Kota Bontang. Tujuan penelitian untuk mengetahui kelayakan kualitas air di Perairan Tihik Tihik Kota Bontang berdasarkan aspek fisika dan kimia perairan. 


\section{Metode Penelitian}

\section{Waktu dan Lokasi Penelitian}

Penelitian ini dilaksanakan pada tanggal 21 April sampai dengan 17 Mei 2021. Lokasi pengambilan sampel terbagi atas 5 titik. Pengambilan sampel di tiap titik stasiun dilakukan sebanyak 3 kali. Adapun titik pengambilan sample tersebut adalah:

1. Perairan Manu-Manukan ( $\left.\mathrm{N}=00^{\circ} 03.381^{\prime}, \mathrm{E}=117^{\circ} 32,1^{\prime} 1^{\prime}\right)$

2. Perairan Gusung Panjang ( $\left.\mathrm{N}=00^{\circ} 03.522^{\prime}, \mathrm{E}=117^{\circ} 32.283^{\prime}\right)$

3. Perairan Tengah Gusung Panjang ( $\left.\mathrm{N}=00^{\circ} 03.456^{\prime}, \mathrm{E}=117^{\circ} 32.013\right)$

4. Perairan Timur Manu-Manukan ( $\left.\mathrm{N}=00^{\circ} 03.386^{\prime}, \mathrm{E}=117^{\circ} 31.947^{\prime}\right)$

5. Perairan Tihik Tihik ( $\mathrm{N}=00^{\circ} 03.554^{\prime}, \mathrm{E}=117^{\circ} 31.957^{\prime}$ )

Pengambilan sampel dilakukan pada pukul 08.00 WITA sampai pukul 17.00 WITA. Sampel dapat diukur secara in situ dan sampel yang perlu dianalisis lebih lanjut, dibawa ke Laboratorium Kualitas Air Fakultas Perikanan dan Kelautan Universitas Mulawarman.

\section{Alat dan Bahan}

Alat dan bahan yang digunakan antara lain tali tambang, secchi disk, water quality checker, laying-layang arus dan alat penyaring miliopor. Untuk analisis nitrat bahan yang digunakan yaitu indicator brucine, asam sulfat pekat $\left(\mathrm{H}_{2} \mathrm{SO}_{4}\right)$, natrium nitrat $\left(\mathrm{NaNO}_{3}\right)$, untuk analisis phosfat digunakan yaitu ammonium molybdate; $\left(\mathrm{NH}_{4}\right) 8 \mathrm{MO}_{7} \mathrm{O}_{24} .4 \mathrm{H}_{2} \mathrm{O}$, asam borat $1 \%\left(\mathrm{H}_{3} \mathrm{BO}_{3}\right)$, asam sulfat $2,5 \mathrm{M}\left(\mathrm{H}_{2} \mathrm{SO}_{4}\right)$, asam ascorbic $1 \%$, kertas saring Whatman no.42. Adapun bahan lain yang digunakan yaitu lugol $100 \mathrm{ml}$, sampel air laut, penyaring millipora (kertas saring watman ukuran pori 0,45 $\mu \mathrm{m}$, tisu dan aquades.

\section{Pengukuran dan Pengambilan Sampel Kualitas Air}

Parameter kualitas perairan yang diukur adalah parameter fisika dan kimia. Parameter fisika meliputi:

1. Pengukuran kedalaman perairan dilakukan dengan menggunakan tali tambang yang ada pada sedimen grab yang sudah diberi tanda untuk tiap meternya

2. Pengambilan data kecerahan air dilakukan dengan menggunakan alat sechii disc, pada setiap titik sampling

3. Suhu perairan diukur dengan menggunakan Water Quality checker tipe Horiba U10A di setiap titik sampling dengan skala pengukuran $1^{\circ} \mathrm{C}$

4. Informasi kecepatan arus diperlukan untuk mengetahui arah dan besarnya massa air yang mengalir. Aliran masa air diukur pada suatu titik yang tetap. Kecepatan arus diukur menggunakan laying-layang arus 
5. Pengukuran muatan padatan tersuspensi adalah menggunakan gravimetrik dengan alat penyaring milliopor (Bapedal, 1996). Selanjutnya dilakukan perhitungan dengan menggunakan rumus (AWWA, 1989) dibawah ini:

$$
\mathrm{MPT}=\frac{(a-b) \times 1000}{c} m g / \text { liter }
$$

Keterangan: $a=$ Berat kertas saring dan residu setelah pemanasan $(\mathrm{mg})$

b = Berat kering filter $(\mathrm{mg})$

c $\quad$ = Volume sampel air laut $(\mathrm{ml})$

Parameter kimia yang diukur meliputi salinitas, $\mathrm{pH}$, oksigen terlarut, phosfat dan nitrat

1. Salinitas diukur menggunakan water quality checker tipe Horiba U10A

2. $\mathrm{pH}$ perairan diukur dengan menggunakan water quality checker tipe Horiba U10A

3. Pengukuran oksigen terlarut menggunakan water quality checker tipe Horiba U10A

4. Pengukuran phosfat dilakukan menurut (Boyd, 1981)

5. Analisis nitrat dilakukan menurut metode (Suin, 1999)

\section{Analisis Data}

Metode penelitian yang dilakukan adalah pengumpulan data primer yang dilakukan dengan pengukuran langsung parameter fisika, dan kimia di lapangan. Analisa kualitas air dilakukan di Laboratorium Kualitas Air, Fakultas Perikanan dan IImu Kelautan Universitas Mulawarman. Data yang diperoleh dianalisa secara deskriptif dan didukung oleh literatur pendukung.

\section{Hasil dan Pembahasan}

Hasil pengukuran kualitas air perairan Tihik Tihik Kota Bontang dapat dilihat pada tabel 1 .

Tabel 1. Analisa kualitas air perairan Tihik Tihik Kota Bontang

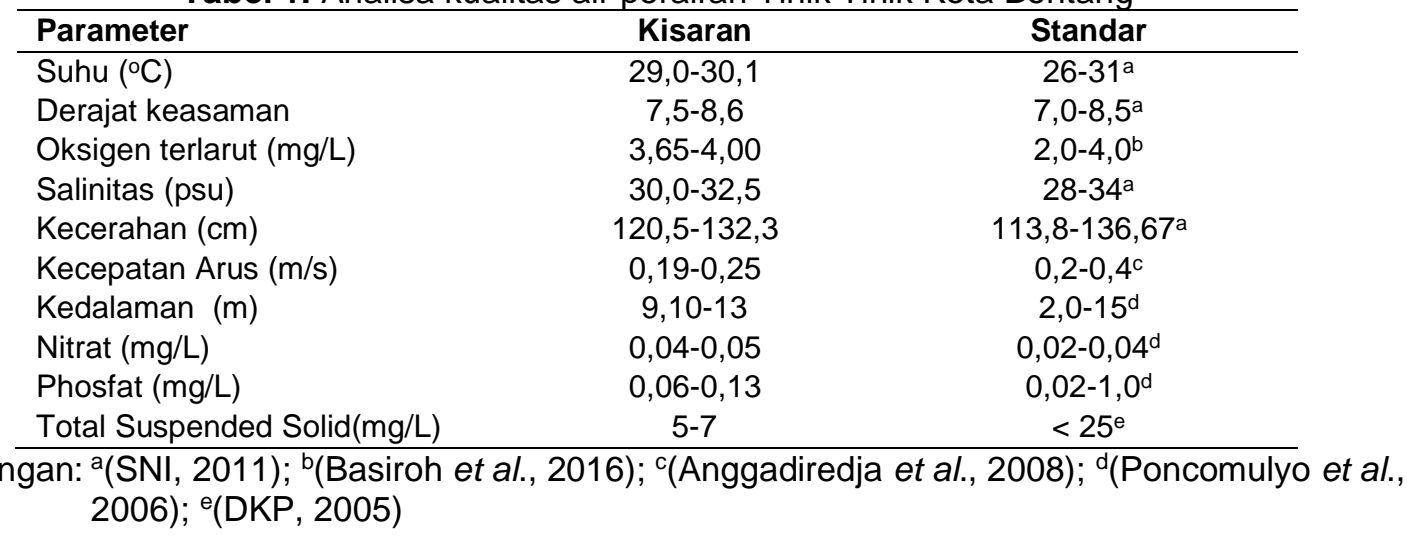

\section{Suhu Perairan}

Suhu merupakan parameter fisika yang sangat mempengaruhi proses fisiologi rumput laut. Proses fisiologi tersebut adalah proses fotosintesis, respirasi, serta proses metabolisme sebagai akibatnya mempengaruhi proses pertumbuhan serta reproduksi organisme. Sesuai dengan hasil pengamatan, diketahui bahwa suhu pada perairan Tihik Jpt. Jurnal Pertanian Terpadu, Jilid 9, Nomor 2| 192 
Tihik berkisar antara $29-30,1^{\circ} \mathrm{C}$. Suhu perairan ini masih berada pada kisaran yang layak untuk budidaya rumput laut. SNI (2011) menyatakan bahwa suhu standar untuk budidaya rumput laut berkisar antara $26-31^{\circ} \mathrm{C}$. Menurut Awaluddin et al., (2016), rumput laut dapat tumbuh dan berkembang dengan baik pada perairan yang memiliki kisaran suhu $26-30^{\circ} \mathrm{C}$. Menurut Anggadiredja et al., (2008), suhu air yang cocok untuk rumput laut Eucheuma sp. antara $20-30^{\circ} \mathrm{C}$. Kisaran suhu perairan sebesar $29-30,1^{\circ} \mathrm{C}$ selama penelitian diduga disebabkan karena curah hujan yang sangat kurang selama proses penanaman dan pemeliharaan. Selain itu bisa juga disebabkan karena kondisi perairan yang jernih sehingga sinar matahari langsung menembus ke kolom perairan dan mengakibatkan suhu cepat naik. Menurut Atmanisa et al., (2020), suhu air yang relatif tinggi juga bisa disebabkan karena waktu pengambilan sampel yang semakin siang, maka suhu semakin naik karena pada waktu siang hari perairan semakin panas dan adanya penyerapan cahaya oleh air akan menyebabkan terjadinya lapisan air yang mempunyai suhu yang berbeda-beda. Menurut Awaluddin et al., (2016), tinggi rendahnya suhu dipengaruhi oleh faktor seperti intensitas cahaya matahari secara langsung, pertukaran panas antara air dengan udara disekelilingnya. Menurut Juniarti et al., (2017)), perbedaan tinggi rendahnya suhu disebabkan pada lapisan permukaan suhu air cenderung dipengaruhi oleh angin. Semakin besar kecepatan angin yang ditimbulkan, maka semakin besar pencampuran suhu air. Suhu yang relatif tinggi juga disebabkan penyinaran matahari yang tinggi dan terus menerus sehingga membawa massa air bersuhu tinggi.

\section{Derajat Keasaman}

Setiap organisme mempunyai toleransi terhadap derajat keasaman yang berbedabeda. Derajat keasaman mempunyai pengaruh yang besar terhadap tumbuhan dan hewan air sehingga sering digunakan sebagai petunjuk untuk menyatakan baik atau buruknya suatu perairan. Derajat keasaman merupakan faktor kimia yang menentukan pertumbuhan rumput laut. Tinggi atau rendahnya derajat keasaman perairan dipengaruhi oleh senyawa/kandungan dalam air, seperti $\mathrm{CO}_{2}$, konsentrasi garam-garam karbonat dan dikarbonat, dan proses dekomposisi bahan organik didasar perairan (Awaluddin et al., 2016). Kisaran derajat keasaman perairan selama penelitian sebesar 7,5-8,6 dan kisaran ini sangat layak untuk pertumbuhan dan perkembangan rumput laut jenis Kapphapycus alvarezii sesuai pendapat SNI (2011) yang menyatakan bahwa kisaran $\mathrm{pH}$ yang optimum untuk jenis rumput laut jenis ini adalah 7,0-8,5.

Menurut pendapat Nur et al., (2016), pengaruh derajat keasaman bagi organisme sangat besar dan penting, kisaran $\mathrm{pH}$ yang kurang dari 6,5 akan menekan laju pertumbuhan bahkan tingkat keasamannya dapat mematikandan tidak ada laju reproduksi sedangkan derajat keasaman sebesar 6,5-9,0 merupakan kisaran optimal dalam suatu perairan. Risnawati et al., (2018), menyatakan bahwa nilai derajat keasaman optimal bagi 
pertumbuhan rumput laut berkisar 6,0-9,0. Perairan yang sangat asam ataupun basa akan membahayakan kehidupan organisme, karena akan mengakibatkan terjadinya gangguan metabolisme serta respirasi.

\section{Oksigen Terlarut (DO)}

Oksigen terlarut (DO) merupakan faktor pembatas bagi semua organisme hidup. Oksigen terlarut merupakan kebutuhan dasar untuk kehidupan mahluk hidup didalam air. Kisaran oksigen terlarut perairan selama penelitian adalah 3,65-4,0 mg/L, masih berada pada kisaran optimum, sesuai pendapat Basiroh et al., (2016,) yang menyatakan bahwa oksigen terlarut yang optimal untuk budidaya rumput laut berkisar 2,0-4,0 mg/L, sedangkan menurut Dirjenkanbud (2008), kandungan oksigen terlarut untuk menunjang usaha budidaya rumput laut adalah 3,0-8,0 mg/L. Risnawati et al., (2018) menyatakan bahwa nilai oksigen terlarut untuk memenuhi syarat tumbuh Kapphapycus alvarezii yaitu 4,5-9,8 mg/L, adanya arus diantara gugusan pulau-pulau kecil dan luasnya padang lamun sangat berpengaruh terhadap tingginya konsentrasi oksigen terlarut perairan.

\section{Salinitas}

Pertumbuhan rumput laut pada lingkungan budidaya salahsatunya ditentukan oleh salinitas dan tekanan osmotik antara rumput laut dengan lingkungan perairan. Setiap organisme memiliki toleransi yang bervariasi. Salinitas sangat mendukung pertumbuhan rumput laut yang dibudidayakan. Kisaran salinitas perairan selama penelitian berkisar 30,0-32,5 per mil menunjukkan kisaran yang cenderung tinggi terhadap pertumbuhan rumput laut. Hal ini terjadi diduga disebabkan oleh musim kemarau yang terjadi saat penelitian dilaksanakan yang secara umum intensitas curah hujan yang relatif kurang. Meskipun masih berada pada kisaran optimal untuk budidaya rumput laut. Salinitas optimal untuk budidaya rumput laut berkisar 28-34 per mil (SNI, 2011).

\section{Kecerahan Perairan}

Kecerahan suatu perairan berhubungan erat dengan penetrasi cahaya matahari yang masuk kedalam perairan. Cahaya tersebut dimanfaatkan oleh rumput laut untuk melakukan proses fotosintesis. Risnawati et al., (2018) menyatakan bahwa cahaya sangat dibutuhkan rumput laut untuk proses fotosintesis. Kecerahan rendah dapat menjadi parameter bahwa cahaya matahari yang masuk kedalam perairan kurang. Kecerahan perairan di lokasi penelitian berkisar $120,5-132,3 \mathrm{~cm}$. Kecerahan perairan yang ideal adalah lebih dari $100 \mathrm{~cm}$. Air keruh (biasanya mengandung lumpur) dapat menghalangi tembusnya cahaya matahari didalam air sehingga proses fotosintesis terganggu. Dengan adanya sinar matahari tersebut Kapphapycus alvarezii dapat melakukan fotosintesis dengan baik. SNI (2011) menyatakan bahwa kisaran optimum kecerahan untuk budidaya rumput laut adalah 113,8-136,67 $\mathrm{cm}$. 
Nilai kecerahan sangat dipengaruhi oleh keadaan cuaca, waktu pengukuran, kekeruhan serta ketelitian orang melakukan pengukuran (Effendi, 2003). Kecerahan perairan berhubungan erat dengan penetrasi cahaya matahari, kecerahan yang baik lebih dari 1 meter. Kondisi air yang jernih dengan tingkat transparansi tidak kurang dari 5 meter cukup baik untuk pertumbuhan rumput laut (Puslitbangkan, 1991).

\section{Kecepatan Arus}

Arus air memiliki peranan yang sangat dibutuhkan pada proses pertumbuhan rumput laut khususnya untuk transpor nutrien, memberikan kemudahan dalam penyerapan nutrien. Risnawati et al., (2018) menyatakan bahwa arus air yang bergerak berfungsi menyuplai zat hara serta membantu rumput laut melakuakn penyerapan serta membersihkan kotoran yang melekat. Kecepatan arus pada perairan Tihik Tihik cenderung lambat walaupun masih berada pada kisaran yang optimal untuk budidaya rumput laut. Kecepatan arus di perairan ini berkisar 0,19-0,25 meter/detik, sedangkan arus optimal untuk budidaya rumput laut berkisar 0,2-0,4 meter/detik (Anggadiredja et al., 2008). Kecepatan arus dilokasi penelitian ini masih dalam kondisi optimal, diduga telah mampu memberikan pasokan berbagai nutrien bagi pertumbuhan rumput laut. Hal ini didukung oleh Nursyahran \& Reskiati (2013) yang menyatakan bahwa pergerakan arus sangat penting dalam penukaran unsur hara, membersihkan kotoran yang menempel, pertukaran oksigen terlarut dalam memperlancar proses fotosintesis. Namun pergerakan air yang terlalu keras akan membahayakan kelangsungan hidup rumput laut.

Perbedaan kecepatan arus dapat disebabkan oleh arus pasang surut maupun karena angin dan ombak. Sejalan dengan pendapat Asni (2015) yang menyatakan bahwa kecepatan arus yang baik untuk budidaya rumput laut adalah $20-40 \mathrm{~cm} / \mathrm{dt}$. Pada lokasi yang kaya nutrien, maka kecepatan arus yang lambat sekitar $10 \mathrm{~cm} / \mathrm{dt}$ sudah dapat mendukung pertumbuhan rumput laut yang baik, sebaliknya pada lokasi yang miskin nutrien diperlukan kecepatan arus yang lebih besar namun tidak melebihi $40 \mathrm{~cm} / \mathrm{dt}$. Dikatakan oleh Kotiya et al., (2011) bahwa arus mengontrol kesuburan lokasi untuk budidaya rumput laut.

Arus mempunyai peranan penting dalam pertumbuhan rumput laut. Jika arus terlalu pelan maka akan mengganggu penyerapan zat hara yang berada di perairan, selain itu arus yang pelan akan berdampak pada epifit-epifit yang tumbuh menempel pada rumput laut akan semakin banyak sehingga dapat menjadi kompetitor dalam mendapatkan nutrien (Asni, 2015). Arus yang terlalu tinggi juga dapat menyebabkan penyerapan unsur hara oleh rumput laut menjadi kurang maksimal. 
Kedalaman Perairan

Kedalaman adalah salah satu faktor yang berpengaruh terhadap penyerapan cahaya oleh rumput laut, karena berkaitan dengan proses fotosintesis yang menghasilkan bahan makanan untuk pertumbuhannya (Susilowati et al., 2012). Kedalaman pada lokasi perairan adalah 9,10-13 m, masih berada pada kisaran yang layak untuk budidaya, dimana kisaran kedalaman yang optimal adalah 2,0-15 m (Poncomulyo et al., 2006).

\section{Nitrat}

Pertumbuhan dan kualitas rumput laut yang dihasilkan berhubungan erat dengan keberadaan nitrat pada perairan. Nitrat adalah unsur hara penting untuk proses pertumbuhan rumput laut. Pramesti (2013) menyatakan bahwa nitrat berperan sebagai penyusun atau bahan dasar protein dan pembentukan klorofil. Nitrogen diserap oleh tanaman dalam bentuk $\mathrm{NO}_{3}\left(\mathrm{~N} \_\mathrm{NO}_{3}\right)$ dan $\mathrm{NH}_{4}{ }^{+}$(N-Amonium) atau keduanya. Tumbuhan yang mengalami kekurangan nitrat berakibat proses fotosintesis dalam tubuhnya juga tidak akan berjalan dengan optimal yang nantinya akan berpengaruh terhadap proses pertumbuhannya.

Kadar nitrat dilokasi penelitian berkisar 0,04-0,05 mg/L. Risnawati et al., (2018) serta Effendi (2003) menyatakan bahwa kadar nitrat diatas 0,2 mg/L menyebabkan timbulnya eutrofikasi (pengayaan) dan akan menstimulir pertumbuhan alga serta tumbuhan air. Aslan (2011) menyatakan bahwa konsentrasi nitrat perairan yang baik untuk pertumbuhan rumput laut adalah 0,0071-0,0169 mg/L. Konsentrasi nitrat pada perairan Tihik Tihik relatif baik untuk pertumbuhan rumput laut serta juga menunjukkan bahwa nitrat merupakan faktor pembatas bagi pertumbuhan rumput laut. Kondisi perairan yang mempunyai konsentrasi nitrat yang tinggi, umumnya dipengaruhi oleh kegiatan yang ada di daratan yang dapat menghasilkan sampah organik dari rumah tangga.

Nitrogen dibutuhkan oleh tanaman untuk proses fotosintesis. Menurut Asni (2015) pertumbuhan alga yang baik membutuhkan kisaran nitrat sebesar 0,9-3,50 ppm Selanjutnya dikatakan oleh Atmanisa et al., (2020) bahwa kebutuhan nitrat setiap alga sangat beragam. Apabila kadar nitrat dibawah $0,1 \mathrm{mg} / \mathrm{L}$ atau diatas $45 \mathrm{mg} / \mathrm{l}$, maka nitrat merupakan faktor pembatas berarti pada kadar demikian nitrat bersifat toksik dan dapat mengakibatkan terjadinya eutrofikasi yang dapat merangsang pertumbuhan fitoplankton dengan cepat (blooming). Adanya kandungan nitrat yang rendah dan tinggi pada kondisi tertentu dapat disebabkan oleh berbagai faktor, antara lain adanya arus yang membawa nitrat dan kelimpahan fitoplankton. 


\section{Phosfat}

Phosfat sangat dibutuhkan rumput laut untuk proses pertumbuhannya dan merupakan salah satu unsur hara yang penting bagi metabolisme sel tanaman. Kandungan phosfat mempengaruhi tingkat kesuburan perairan (Susilowati et al., 2012). Phosfat yang diserap rumput laut umumnya dalam bentuk ortophosfat. Hasil penelitian menunjukkan bahwa kandungan phosfat perairan berkisar 0,06-0,13 mg/L. Menurut Anggadiredja et al., (2008), kandungan phosfat yang cocok untuk budidaya rumput laut berkisar 0,02-1,04 mg/L.

Tingginya kadar phosfat pada perairan diduga disebabkan karena tingginya difusi phosfat dari sedimen, sesuai pendapat Patty et al., (2015) yang menjelaskan bahwa sedimen adalah tempat penyimpanan utama phosfat dalam laut, yang berbentuk partikulat dengan senyawa hidroksida dan oksida besi. Phosfat dapat mengalami dekomposisi dengan bantuan bakteri maupun melalui proses abiotik menghasilkan senyawa phosfat terlarut yang dapat mengalami difusi kembali ke kolom air. Selain itu tingginya kadar phosfat juga diduga disebabkan karena perairan tempat pengambilan sampel merupakan perairan yang semi tertutup yang nyaris terisolasi dari perairan lepas pantai sehingga sirkulasi airnya kurang baik. Kondisi ini didukung oleh aktivitas masyarakat sekitarnya. Bisa dipastikan bahwa sumber utama penyumbang phosfat ke dalam perairan adalah limbah domestik masyarakat. Menurut. Volterra et al., (2002), pengkayaan phosfat terutama berasal dari limbah rumah tangga dan industri, termasuk detergen berbahan dasar phosfor.

\section{TSS (Total Padatan Tersuspensi)}

Total padatan tersuspensi (TSS) artinya endapan yang dapat berakibat kekeruhan dalam perairan karena adanya partikel yang tidak larut dan mengendap. Padatan tersuspensi ini menghalangi penetrasi cahaya matahari yang masuk ke perairan dan menutupi thallus rumput laut sehingga menghalangi proses fotosintesis. Kandungan padatan tersuspensi pada perairan Tihik Tihik berkisar 5-7 mg/L, ini menunjukkan kondisi yang optimal, karena menurut DKP (2005), kandungan TSS yang cocok untuk budidaya rumput laut berkisar <25 mg/L. Ya'la \& Sulistiawati (2016) menyatakan bahwa zat padat tersuspensi merupakan tempat berlangsungnya reaksi-reaksi heterogen dan berfungsi sebagai bahan pembentuk endapan yang paling awal dan dan dapat menghalangi kemampuan produksi zat organik di suatu perairan. Bahan-bahan terlarut berasal dari bahan buangan yang berbentuk padat. Bahan buangan jika tidak dapat larut sempurna akan mengendap di substrat, tetapi sebelum mengendap akan melayang-layang dalam air dan menghalangi penetrasi cahaya matahari. Berdasarkan kisaran padatan tersuspensi di perairan Tihik Tihik layak untuk pertumbuhan rumput laut Kappaphycus alvarezii. 


\section{Kesimpulan}

Hasil penelitian yang telah dilakukan dapat disimpulkan bahwa parameter fisika dan kimia perairan Tihik Tihik seperti suhu, derajat keasaman, oksigen terlarut, salinitas, kecerahan, kecepatan arus, kedalaman, nitrat, phosfat, total padatan tersuspensi, masih berada pada kisaran yang layak untuk dijadikan media budidaya rumput laut, khususnya rumput laut jenis Kapphapycus alvarezii. Penelitian selanjutnya disarankan untuk mengukur parameter biologi, tinggi gelombang dan biota predator karena ketiga parameter tersebut sangat berpengaruh terhadap pertumbuhan rumput laut

\section{Daftar Pustaka}

American Water Works Association (AWWA). (1989). Standar Methods for the Examination of Water and Wastewater. 17th edition. Washington, DC: American Public Health Association.

Anggadiredja, J. T., Zatnika, A., Purwoto, H., \& Istini, S. (2008). Potential and Prospect of Indonesia Seaweed Industry Development. The Indonesia Agency For The Assessment And Application Of Technology - Indonesia Seaweed Society. Jakarta, 28 hal.

Aslan, L. M. (2011). Strategi Pengembangan Budidaya Rumput Laut Di Indonesia. Pidato Pengukuhan Guru Besar Dalam Bidang Budidaya. Fakultas Perikanan Dan IImu Kelautan. Universitas Haluoleo, Kendari.

Asni, A. (2015). Analisis Produksi Rumput Laut (Kappaphycus alvarezii) Berdasarkan Musim dan Jarak Lokasi Budidaya Di Perairan Kabupaten Bantaeng. Jurnal Akuatika Indonesia, 6(2), 140-153.

Atmanisa, A., Mustarin, A., \& Taufieq, N. A. S. (2020). Analisis Kualitas Air pada Kawasan Budidaya Rumput Laut Eucheuma Cottoni di Kabupaten Jeneponto. Jurnal Pendidikan Teknologi Pertanian, 6(1), 11-22. https://doi.org/10.26858/jptp.v6i1.11275

Awaluddin, Badraeni, Azis, H. Y., \& Tuwo, A. (2016). Perbedaan Kandungan Karaginan dan Produksi Rumput Laut Kappaphycus alvarezii antara Bibit Alam dan Bibit Hasil Pengayaan. Jurnal Rumput Laut Indonesia, 1(1), 65-70.

Badan Pengendalian Dampak Lingkungan (Bapedal). (1996). Pedoman Teknis Pengendalian Pencemaran Udara Sumber Tidak Bergerak. 138 hal.

Basiroh, S., Ali, M., \& Putri, B. (2016). Pengaruh periode panen yang berbeda terhadap kualitas karaginan rumput laut Kappaphycus alvarezii: Kajian Randemen dan Organoleptik Karaginan. Maspari Journal, 8(2), 127-134.

Boyd, C. E. (1981). Water Quality in Ponds for Aquaculture. Birmingham: Birmingham Publishing Co.

Departemen Kelautan dan Perikanan (DKP). (2005). Modul Sosialisasi dan Orientasi Penataan Ruang Laut, Pesisir dan Pulau-pulau Kecil. Jakarta: Ditjen Pesisir dan Pulau-Pulau Kecil.

Direktur Jenderal Perikanan Budidaya (Dirjenkanbud). (2008). Profil. Rumput Laut Indonesia. Jakarta: Direktur Jenderal Perikanan Budidaya.

Effendi, H. (2003). Telaah Kualitas Air Bagi Pengolahan Sumberdaya Hayati Lingkungan Perairan. Yogyakarta: Kanisius. 
Juniarti, L., Jumarang, M. I., \& Apriansyah. (2017). Analisis Kondisi Suhu Dan Salinitas Perairan Barat Sumatera Menggunakan Data Argo Float. Physic Communication, 1(1), 74-84. https://doi.org/10.15294/physcomm.v1i1.9005

Kotiya, A. ., B. Gunalan, Parmar, H. V., Tushar, D., Jitesh, B. S., \& P.Makwana, N. (2011). Growth Comparison of the Seaweed Kappaphycus alvarezii in Nine Different Coastal Areas of Gujarat Coast, India. Advances in Applied Science Research, 2(3), 99-106.

Kumayanjati, B.-, \& Dwimayasanti, R. (2018). Kualitas Karaginan dari Rumput Laut Kappaphycus alvarezii pada Lokasi Berbeda di Perairan Maluku Tenggara. Jurnal Pascapanen Dan Bioteknologi Kelautan Dan Perikanan, 13(1), 21-32. https://doi.org/10.15578/jpbkp.v13i1.490

Nur, A. I., Syam, H., \& Patang. (2016). Pengaruh Kualitas Air Terhadap Produksi Rumput Laut (Kapphapycus alvarezii). Jurnal Pendidikan Teknologi Pertanian, 2(1), 27-40. https://doi.org/10.26858/jptp.v2i1.5151

Nursyahran, \& Reskiati. (2013). Peningkatan Laju Pertumbuhan Thallus Rumput Laut Kapphaphycus alvarezii Yang Direndam Air Beras Dengan Konsentrasi Yang Berbeda. Jurnal Balik Diwa, 4(2), 13-18.

Patty, S. I., Arfah, H., \& Abdul, M. S. (2015). Nutriens (Phosphate, Nitrate), Dissolved Oxygen, and Dissolved $\mathrm{pH}$ and They Relation to Productivity of Jikumerasa Waters, Buru Island. Jurnal Pesisir Dan Laut Tropis, 1(1), 43-50. https://doi.org/10.35800/jplt.3.1.2015.9578

Poncomulyo, T., Maryani, H., \& Kristiana, L. (2006). Budi Daya \& Pengolahan Rumput Laut. Jakarta: AgroMedia Pustaka.

Pramesti, R. (2013). Aktivitas Antioksidan Ekstrak Rumput Laut Caulerpa serrulata Dengan Metode DPPH (1,1 difenil 2 pikrilhidrazil). Buletin Oseanografi Marina, 2(April 2013), 7-15. https://doi.org/10.14710/buloma.v2i2.6931

Pusat Penelitian dan Pengembangan Perikanan (Puslitbangkan). (1991). Budidaya rumput Laut (Eucheuma sp) dengan Rakit dan Lepas Dasar. Jakarta: Pusat Penelitian dan Pengembangan Perikanan.

Risnawati, Kasim, M., \& Haslianti. (2018). Studi Kualitas Air Kaitanya dengan Pertumbuhan Rumput Laut (Kappaphycus alvarezii) Pada Rakit Jaring Apung Di Perairan Pantai Lakeba Kota Bau-Bau Sulawesi Tenggara. Jurnal Manajemen Sumber Daya Perairan, 4(2), 155-164.

Standar Nasional Indonesia (SNI). (2011). Standar Nasional Indonesia (SNI) 7673.2:2011. Produksi Bibit Rumput Laut Kotoni (Eucheuma cottonii) - Bagian 2: Metode Longline. Jakarta: BSNI.

Suin, N. M. (1999). Metode Ekologi. Jakarta: Ditjen Pendidikan Tinggi. Departemen Pendidikan dan Kebudayaan.

Susilowati, T., Rejeki, S., Dewi, E. N., \& Zulfitriani. (2012). Pengaruh Kedalaman Terhadap Pertumbuhan Rumput Laut (Eucheuma cottonii) Yang Dibudidayakan Dengan Metode Longline Di Pantai Mlonggo, Kabupten Jepara. Jurnal Saintek Perikanan, 8(1), 7-12. https://doi.org/10.14710/ijfst.8.1.7-12 
Volterra, L., Boualam, M., Ménesguen, A., Duguet, J.-P., Duchemin, J., \& Bonnefoy, X. (2002). Eutrophication and Health (K. Pond, Ed.). Luxembourg: World Health Organization (WHO) \& European Commission: Office for Official Publications of the European Communities.

Ya'la, Z. R., \& Sulistiawati, D. (2016). Kajian Pertumbuhan Rumput Laut Eucheuma cottonii dan Beberapa Parameter Kualitas Air Yang Mempengaruhi Pada Tambak Polikultur. Prosiding Semnas Hasil Penelitian Dan Pengabdian Kepada Masyarakat: Inovasi IPTEKS Perguruan Tinggi Untuk Meningkatkan Kesejahteraan Masyarakat. Denpasar - Provinsi Bali 29-30 Agustus 2016, 1000-1008. Denpasar: Lembaga Penelitian dan Pemberdayaan Masyarakat (LPPM) Unmas Denpasar.

Zainuddin, F., \& Rusdani, M. M. (2018). Performa Rumput Laut Kapphapycus alvarezii dari Maumere dan Tembalang Pada Budidaya Sistem Longline. Journal of Aquaculture Science, 3(1), 17-28. https://doi.org/10.31093/joas.v3i1.37 